\title{
FORMULASI SEDIAAN KUMUR DARI EKSTRAK DAUN SUKUN Artocarpus altilis (Parkinson ex F.A.Zorn) Fosberg
}

\author{
Yahdian Rasyadi* \\ Sekolah Tinggi Farmasi Indonesia Perintis Padang \\ Jalan Adinegoro KM. 17, Batipuh Panjang, Kota Padang, Sumatera Barat 25586 \\ e-mail: yahdianrasyadi@gmail.com
}

Diterima: 19 Oktober 2018 / Disetujui: 11 Desember 2018 / Dipublikasi online: 15 Desember 2018 DOI: $10.22437 /$ chp.v3i2.5767

\begin{abstract}
I has been studied research on mouthwash formulations from breadfruit leaf extract. This study aims to be able to formulate breadfruit leaf extract into mouth rinses. Mouthwashes breadfruit leaf extract is made into four formula that FO (base), F1 (extract of breadfruit leaf pods 10\%), F2 (extract of breadfruit leaf pods 15\%) and F3 (extract of breadfruits leaf pods 20\%). Evaluation of mouthwash includes organoleptic examination, $p H$, stability, and viscosity. The evaluation results show that the physical properties performed mouthwash give good results and qualify mouthwash preparations. Breadfruit leaf extract could be formulated in the form of mouthwash.
\end{abstract}

Keywords: breadfruit leaf extract; mouthwash formulations; Mouthwashes breadfruit leaf extract

\begin{abstract}
ABSTRAK
Telah dilakukan penelitian tentang formulasi sediaan kumur dari ekstrak daun sukun (Artocarpus altilis). Penelitian ini bertujuan untuk dapat memformulasi ekstrak daun sukun menjadi sediaan kumur. Sediaan kumur ekstrak daun sukun dibuat menjadi empat formula yaitu FO (basis), F1 (ekstrak daun sukun 10\%), F2 ( ekstrak daun sukun 15\%) dan F3 ( ekstrak daun sukun 20\%). Evaluasi obat kumur meliputi pemeriksaan organoleptis, $\mathrm{pH}$, stabilitas, dan viskositas. Hasil evaluasi menunjukkan bahwa sifat fisik sediaan obat kumur memberikan hasil yang baik dan memenuhi syarat sediaan obat kumur. Ekstrak daun sukun dapat diformulasi dalam bentuk sediaan obat kumur.
\end{abstract}

Kata Kunci: ekstrak daun sukun, formulasi obat kumur, obat kumur daun sukun

\section{PENDAHULUAN}

Pemanfaatan tumbuhan sebagai bahan obat tradisional telah lama digunakan oleh masyarakat Indonesia, sebagian masih berdasarkan pengalaman turun temurun dan sebagian lagi telah dikembangkan melalui penelitian ilmiah. Sejak dahulu sampai sekarang masyarakat telah menggunakan tanaman yang diolah secara resep tradisonal nenek moyang dalam penyembuhan penyakit. Banyak tanaman yang tersebar di Indonesia membuat sebagian masyarakat belum menyadari bahwa di sekitar mereka ada banyak tanaman yang berkhasiat sebagai obat (Hariana, 2008).

Salah satu tanaman yang dirpecaya dapat dijadikan obat adalah sukun (Artocarpus altilis (Parkinson ex F.A.Zorn) Fosberg) yaitu tanaman herbal yang mempunyai banyak manfaat. Tanaman ini mampu tumbuh di berbagai tempat karena daya adaptasinya yang tinggi. Tumbuhan ini tumbuh baik di daerah basah dan juga mampu tumbuh di daerah yang sangat kering. Bahkan pada musim kemarau sukun dapat tumbuh dan berbuah 
sangat dengan lebat. Tanaman sukun memiliki ragam manfaat, seluruh dari bagian tanaman ini telah dimanfaatkan sebagai obat tradisional terutama daunnya (Mardiana, 2013).

Beberapa penyakit dapat diobati dengan daun sukun antara lain hepatitis, pembesaran limfa dan kencing manis. Hal tersebut dikarenakan daun sukun mengandung senyawa steroid, fenol, dan flavonoid. Senyawa flavonoid yang terkandung dalam daun sukun berfungsi sebagai antimikroba seperti virus, bakteri, dan jamur (Mardiana, 2013).

Halitosis adalah bau nafas tak sedap yang keluar dari rongga mulut. Sampai saat ini, halitosis merupakan salah satu masalah kesehatan mulut yang banyak dikeluhkan masyarakat setelah karies dan penyakit periodontal (Wijayanti et al., 2010). Salah satu cara untuk mengatasi bau mulut yaitu dengan menggunakan obat kumur (mouthwash) yang mengandung bahan antibakteri. Obat kumur (mouthwash) adalah formula berupa larutan, umumnya dalam bentuk pekat yang harus diencerkan dahulu sebelum digunakan, dimaksudkan untuk digunakan sebagai pencegahan atau pengobatan infeksi tenggorok. Menurut definisi yang lain, obat kumur (mouthwash) adalah larutan yang biasanya mengandung bahan penyegar nafas, astringen, demulsen atau surfaktan, atau antibakteri untuk menyegarkan dan membersihkan saluran pernafasan yang pemakaiannya dengan berkumur (Akarina, 2011).

\section{METODOLOGI PENELITIAN}

\section{Alat}

Alat - alat yang digunakan pada penelitian ini adalah batang pengaduk, (Pyrex), corong, Erlenmeyer (Pyrex), gelas ukur (Witeg), blender, jangka sorong, kertas indikator $\mathrm{pH}$, oven (memmet), pinset, rotavator, timbangan analitik (Mettler), pipet skala, sendok tanduk, spoit, pencadang, tabung reaksi (Pyrex), lemari pendingin, rak tabung, botol vial, dan jangka sorong.

\section{Bahan}

Bahan - bahan yang digunakan pada penelitian ini adalah daun sukun Artocarpus altilis (Parkinson ex F.A.Zorn) Fosberg, etanol 70\%, gliserin, Mentol, propilenglikol, Nasakarin, aquades, Formula Pembanding "BOK", kertas label, kertas saring dan aluminium foil.

\section{Prosedur Penelitian}

Pengambilan Sampel

Sampel yang digunakan pada penelitian ini adalah sampel daun sukun (Artocarpus altilis (Parkinson ex F.A.Zorn) Fosberg) yang diambil dari daerah sekitar Mesjid Al- Amin Lubuk Buaya, Padang. Sampel basah kemudian dicuci bersih dikeringkan dengan cara diangin-anginkan sampai kering tanpa menggunakan cahaya matahari langsung kemudian diserbukkan dengan derajat halus sesuai dengan derajat halus yang umum untuk simplisia. 


\section{Ekstraksi Sampel}

Maserasi dilakukan dengan menggunakan etanol 70\%. Simplisia ditimbang dan diperoleh hasil simplisia sebanyak 1300 gram. Sebanyak 1300 gram simpisia kemudian direndam dalam $5000 \mathrm{ml}$ etanol 70\%. Maserasi dilakukan selama 3 hari sambil sesekali diaduk. Hasil maserasi kemudian disaring untuk memisahkan cairan etanol dengan ampasnya. Dilakukan remaserasi selama 3 hari kemudian dilakukan penyaringan. Ekstrak cair lalu dimasukkan ke dalam labu Erlenmeyer bulat lalu diuapkan dengan rotari evaporator untuk memperoleh ekstrak kental (Fendri et al., 2018; Lely et al., 2018; Sari et al., 2018).

Uji Fitokimia

Uji fitokimia meliputi : Uji Flavonoid, Uji Fenolik, Uji Saponin, Uji Alkaloid, dan Uji Terpenoid dan Steroid (Harborne, 1987; Yulia dan Hidayana, 2017; Hidayatullah et al., 2018).

\section{Pemeriksaan Organoleptis}

Pemeriksaan organoleptis dilakukan secara visual dengan mengamati bentuk, warna, rasa dan bau dari ekstrak (Lely et al., 2017; Rahmi et al., 2018)

\section{Pemeriksaan Kelarutan}

Pemeriksaan kelarutan dilakukan dengan melarutkan ekstrak kental pada air dan etanol 95\%.

\section{Penentuan Rendemen Ekstrak}

Rendemen ekstrak dihitung dengan cara membandingkan berat ekstrak kental yang didapat dengan berat daun sukun awal (Afrianti et al., 2017).

$$
\% \text { Rendemen }=\frac{\text { Berat ekstrak }}{\text { Berat sampel awal }} \times 100 \%
$$

\section{Pemeriksaan Susut Pengeringan}

Ekstrak kental ditimbang 1 gram dimasukan kedalam cawan penguap yang sebelumnya telah dipanaskan pada suhu $105^{\circ} \mathrm{C}$ selama 30 menit didalam oven dan ditimbang. Kemudian dimasukkan cawan penguap yang berisi ekstrak ke dalam oven pada suhu $105{ }^{\circ} \mathrm{C}$ selama $2 \mathrm{jam}$, lalu didinginkan dalam desikator dan ditimbang sampai diperoleh bobot tetap (Departemen Kesehatan RI, 1995; Noviyanty \& Hepiyansori, 2018).

$$
\% \text { Susut Pengeringan }=\frac{(B-A)-(C-A)}{(B-A)} \times 100 \%
$$

Keterangan :

$$
\begin{aligned}
& \mathrm{A}=\text { Berat krus kosong } \\
& \mathrm{B}=\text { Berat krus }+ \text { sampel sebelum dipanaskan } \\
& \mathrm{C}=\text { Berat krus }+ \text { sampel setelah dipanaskan }
\end{aligned}
$$

\section{Pemeriksaan Kadar Abu}

Ekstrak ditimbang sebanyak 3 gram, kemudian dimasukkan kedalam krus porselen yang telah dipijar sebelumnya. Krus didinginkan dalam desikator dan dimasukkan 
kedalam furnes suhu $600^{\circ} \mathrm{C}$ selama 6 jam, hingga arang habis yang ditandai dengan warna abu-abu. Setelah dingin, ditimbang dan dihitung kadar abu (Departemen Kesehatan RI, 1995; Aria et al., 2017). Kadar abu dihitung dengan rumus:

$$
\% \quad \text { Kadar abu }=\frac{\mathrm{C}-\mathrm{A}}{\mathrm{B}-\mathrm{A}} \times 100 \%
$$

Keterangan :

$$
\begin{aligned}
& \mathrm{A}=\text { Berat krus kosong } \\
& \mathrm{B}=\text { Berat krus + sampel sebelum pemijaran } \\
& \mathrm{C}=\text { Berat krus + sampel setelah pemijaran }
\end{aligned}
$$

\section{Pemeriksaan pH Ekstrak}

Pemeriksaan $\mathrm{pH}$ ekstrak dilakukan dengan menggunakan $\mathrm{pH}$ meter. Alat dikalibrasi terlebih dahulu dengan menggunakan larutan dapar $\mathrm{pH}$ 4, $\mathrm{pH}$ 7, dan larutan dapar $\mathrm{pH} 10$. Angka yang muncul pada alat berada pada harga $\mathrm{pH}$ larutan tersebut. Kemudian elektroda dicuci dengan aquadest dan dikeringkan dengan tisu. Pengukuran $\mathrm{pH}$ ekstak kental dilakukan dengan cara mengencerkan 1 gram ekstrak dengan aquadest hingga $10 \mathrm{ml}$ dalam wadah yang cocok. Elektroda dicelupkan kedalam wadah tersebut dan dibiarkan angka bergerak sampai posisi konstan. Angka yang ditunjukkan $\mathrm{pH}$ meter merupakan harga pH ekstrak (Departemen Kesehatan RI, 1995; Ningsih et al., 2017).

\section{Formulasi Sediaan Kumur}

Formula sediaan kumur dari ekstrak daun sukun dapat dilihat di Tabel 1.

Tabel 1. Formula sediaan kumur ekstrak daun sukun.

\begin{tabular}{lrrrr}
\hline \multirow{2}{*}{ Bahan } & \multicolumn{4}{c}{ Formula } \\
\cline { 2 - 5 } & F0 & F1 & F2 & F3 \\
\hline Ekstrak daun sukun (\%) & 0,00 & 10,00 & 15,00 & 20,00 \\
Gliserin (\%) & 15,00 & 15,00 & 15,00 & 15,00 \\
Propilenglikol (\%) & 10,00 & 10,00 & 10,00 & 10,00 \\
Na-Sakarin (\%) & 0,10 & 0,10 & 0,10 & 0,10 \\
Menthol (\%) & 0,25 & 0,25 & 0,25 & 0,25 \\
Etanol 70\% (ml) & 0,10 & 0,10 & 0,10 & 0,10 \\
Aquades hingga (ml) & 100,00 & 100,00 & 100,00 & 100,00 \\
\hline
\end{tabular}

Pembuatan Sediaan Kumur

Larutan sediaan kumur dibuat dengan melarutkan ekstrak daun sukun dengan propilenglikol, kemudian ditambahkan aquadest dan gliserin sampai larut (M1). Menthol digerus dan dilarutkan dengan etanol sampai larut (M2). Selanjutnya Na Sakarin dilarutkan kedalam $10 \mathrm{ml}$ air hingga larut. Kemudian (M1) dan (M2) dicampur hingga larut dan dtambahkan aquadest ad $100 \mathrm{ml}$. Dihomogenkan dengan magnetic stirrer kecepatan 100 rpm selama 15 menit. Larutan sediaan kumur yang telah dibuat dimasukkan kedalam wadah tertutup rapat dan disimpan ditempat sejuk untuk dilakukan evaluasi.

\section{Evaluasi Organoleptis}

Evaluasi sediaan kumur dilakukan dengan mengamati dari segi rasa, bentuk, warna, aroma dan kejernihan. Pemeriksaan ini dilakukan pada suhu kamar $\left(15-30{ }^{\circ} \mathrm{C}\right)$ 
setiap minggu selama 6 minggu (Departemen Kesehatan RI, 1995; Rahim et al., 2011; Rahim et al., 2016).

\section{Evaluasi Viskositas}

Pengukuran viskositas sediaan dilakukan dengan menggunakan viskometer ostwald. Isi tabung dengan sejumlah tertentu sampel (suhu diatur pada 20,0 $\pm 0,1^{\circ} \mathrm{C}$ ) sebagaimana dinyatakan oleh pabrik. Meniskus cairan dalam tabung kapiler diatur hingga garis graduasi teratas dengan bantuan tekanan atau pengisapan. Buka kedua tabung pengisi dan tabung kapiler agar cairan dapat mengalir bebas ke dalam wadah melawan tekanan atmosfir. Waktu yang diperlukan cairan untuk mengalir dari batas atas hingga batas bawah dalam tabung kapiler dicatat (Departemen Kesehatan RI, 1995).

$$
\frac{\eta 1}{\eta 2}=\frac{t 1 . \rho 1}{t 2 . \rho 2}
$$

dimana $\eta 1$ = Viskositas cairan sampel (sentipoice $(\mathrm{cP})$ ); $\eta 2=$ Viskositas cairan pembanding $($ sentipoice $(\mathrm{cP})) ; \rho 1=$ Massa Jenis dalam cairan sampel $(\mathrm{gram} / \mathrm{mL}) ; \rho 2=$ Massa Jenis dalam cairan pembanding (gram $/ \mathrm{mL}) ; \mathrm{t} 1$ = Waktu aliran cairan sampel (detik); dan $\mathrm{t} 2=$ Waktu aliran cairan pembanding (detik).

Pemeriksaan $\mathrm{pH}$

Pemeriksaan ini dilakukan menggunakan alat $\mathrm{pH}$ meter. Alat ini dikalibrasi terlebih dahulu menggunakan larutan dapar $\mathrm{pH} 4$ dan $\mathrm{pH}$ 7. Elektroda dibilas dengan air suling dan dikeringkan. Pengukuran $\mathrm{pH}$ obat kumur dilakukan dengan cara elektroda dicelupkan dalam wadah tersebut, angka yang ditunjukkan pada $\mathrm{pH}$ meter merupakan nilai $\mathrm{pH}$ ekstrak tersebut. Pemeriksaan dilakukan setiap minggu selama 6 minggu (Departemen Kesehatan RI, 1995; Rahim et al., 2011).

\section{Stabilitas}

Pemeriksaan stabilitas bertujuan melihat apakah terjadi permisahan fase dalam sediaan selama proses penyimpanan. Pemeriksaan stabilitas dilakukan dengan menggunakan Metode Freeze and Thaw dengan cara sediaan sebanyak $2 \mathrm{ml}$ dimasukan kedalam 8 vial dan ditutup rapat. Sebanyak 4 vial digunakan sebagai kontrol disimpan pada suhu $25^{\circ} \mathrm{C}$. Sisa 4 vial lagi akan digunakan untuk siklus Freeze and Thaw dengan cara vial disimpan pada suhu $4^{\circ} \mathrm{C}$ selama 24 jam, kemudian dilanjutkan disimpan pada suhu $40^{\circ} \mathrm{C}$ selama 24 jam, diamati perubahan organoleptisnya (1 siklus). Dilakukan hingga 6 siklus dan diamati perubahan organoleptisnya tiap siklus (ICH, 2003; Rahim et al., 2016).

\section{PEMBAHASAN}

Hasil pemeriksaan organoleptis ekstrak daun sukun Artocarpus altilis (Parkinson ex F.A.Zorn) Fosberg yaitu ekstrak berbentuk padat, berwarna coklat kehijauan, berbau tajam, dan berasa tawar. Kelarutan ekstrak di dalam air agak sukar larut $(1: 51,2)$ dan dalam etanol 96\% mudah larut (1:11,7). Larutan 10\% ekstrak daun sukun diperoleh nilai 
pH 6,27. Hasil pemeriksaan susut pengeringan ekstrak daun sukun diperoleh nilai susut pengeringan sebesar 19,97\%. Hasil pemeriksaan kadar abu ekstrak daun sukun diperoleh nilai kadar abu sebesar 4,61\%. Rendemen hasil ekstraksi daun sukun menggunakan pelarut etanol $70 \%$, sebanyak 1300 gram daun sukun kering diperoleh ekstrak kental sebesar 82,5 gram dengan nilai rendemen sebesar 6,34\%.

Pengujian fitokimia memberikan hasil bahwa ekstrak daun sukun positif mengandung senyawa flavonoid, fenolik, saponin, alkaloid, terpenoid. Pemeriksaan organoleptis sediaan kumur ekstrak daun sukun dilakukan selama 6 minggu, bertujuan untuk melihat tampilan fisik suatu sediaan. Pemeriksaan organoleptis meliputi bentuk, warna dan bau dan diperoleh hasil FO berbentuk larutan, warna bening, tidak berbau, rasa manis menyegarkan, F1 berbentuk larutan, warna kuning, bau khas sukun, rasa manis segar khas sukun, F2 berbentuk larutan, warna kuning kecoklatan, bau khas sukun, rasa manis segar khas sukun, F3 berbentuk larutan, warna kuning kecoklatan pekat, bau khas sukun, rasa manis segar khas sukun. Terdapat perbedaan pada F3 dimana konsentrasi ekstrak daun sukun lebih besar sehingga warna sediaan lebih gelap dibandingkan F2 dan F1. Dari hasil evaluasi organoleptis yang meliputi pemeriksaan bentuk, bau, warna dan rasa, selama 6 minggu tidak terjadi perubahan selama penyimpanan. Hal ini mengindikasikan bahwa sediaan obat kumur stabil selama penyimpanan secara fisika (Gambar 1).

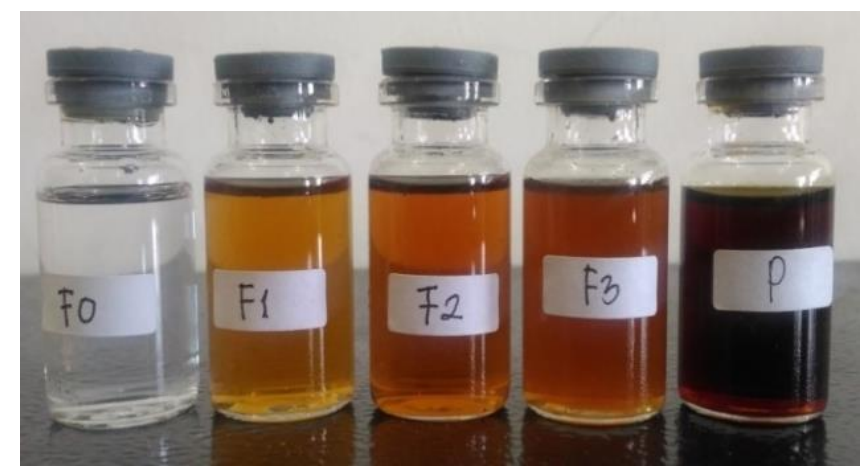

Gambar 1. Sediaan kumur ekstrak daun sukun

Evaluasi $\mathrm{pH}$ sediaan kumur dilakukan selama 6 minggu. Nilai rata - rata $\mathrm{pH}$ sediaan kumur yang didapatkan (Tabel 2) berkisar antara 6,65 - 7,69, dimana nilai rata rata $\mathrm{pH}$ dari $\mathrm{FO}=7,69 \pm 0,06, \mathrm{~F} 1=6,65 \pm 0,04, \mathrm{~F} 2=6,66 \pm 0,03, \mathrm{~F} 3=6,68 \pm 0,05, \mathrm{P}=$ 6,69 $\pm 0,09$. Hasil uji menunjukkan $\mathrm{pH}$ berubah-ubah setiap minggu, namun masih memenuhi rentang $\mathrm{pH}$ fisiologis mulut. Perubahan nilai $\mathrm{pH}$ tiap minggu mungkin disebabkan oleh faktor lingkungan seperti suhu, penyimpanan dan sensitivitas dari alat $\mathrm{pH}$ meter. Nilai $\mathrm{pH}$ obat kumur yang dihasilkan harus berada pada rentang $\mathrm{pH}$ rongga mulut yang berkisar antara 5,5 - 7,9 (Barman dan Prasad, 2015) sehingga pada saat sediaan dikonsumsi tidak menimbulkan iritasi pada mukosa mulut.

Pemeriksaan stabilitas obat kumur dilakukan untuk melihat kestabilan obat kumur selama waktu penyimpanan. Pemeriksaan stabilitas sediaan dilakukan pada suhu tinggi $\left(40^{\circ} \mathrm{C}\right)$ selama 6 minggu. Hasil pemeriksaan menunjukkan bahwa basis sediaan kumur dan 
sediaan kumur ekstrak daun sukun pada konsentrasi 10\%, 15\% dan 20\% tidak memisah dan tidak terjadi perubahan fisik sampai minggu ke 6 (Tabel 3). Ini menunjukkan bahwa sediaan obat kumur stabil dengan berbagai suhu.

Tabel 2. Hasil pemeriksaan pH sediaan kumur ekstrak daun sukun

\begin{tabular}{|c|c|c|c|c|c|c|c|}
\hline \multirow[t]{2}{*}{ Formula } & \multicolumn{6}{|c|}{ pH Minggu ke- } & \multirow{2}{*}{$\begin{array}{c}\text { Rata - rata } \pm \\
\text { SD }\end{array}$} \\
\hline & 1 & 2 & 3 & 4 & 5 & 6 & \\
\hline FO & 7,76 & 7,64 & 7,69 & 7,59 & 7,64 & 7,69 & $7,69 \pm 0,06$ \\
\hline $\mathrm{F} 1$ & 6,65 & 6,69 & 6,68 & 6,58 & 6,68 & 6,63 & $6,65 \pm 0,04$ \\
\hline $\mathrm{F} 2$ & 6,67 & 6,69 & 6,69 & 6,60 & 6,65 & 6,67 & $6,66 \pm 0,03$ \\
\hline F3 & 6,73 & 6,70 & 6,66 & 6,68 & 6,76 & 6,59 & $6,68 \pm 0,05$ \\
\hline $\mathrm{P}$ & 6,79 & 6,70 & 6,73 & 6,56 & 6,78 & 6,58 & $6,69 \pm 0,09$ \\
\hline
\end{tabular}

Dimana F0 = Formula basis sediaan kumur; F1 = Formula sediaan kumur ekstrak daun sukun 10\%; F2 = Formula sediaan kumur ekstrak daun sukun 15\%; F3 = Formula sediaan kumur ekstrak daun sukun 20\%; P = Formula Pembanding "BOK".

Tabe1 3. Hasil pemeriksaan stabilitas sediaan kumur ekstrak daun sukun

\begin{tabular}{|c|c|c|c|c|c|c|c|}
\hline \multirow{2}{*}{ Formula } & \multirow{2}{*}{ Organoleptis } & \multicolumn{6}{|c|}{ Siklus ke- } \\
\hline & & I & II & III & IV & V & VI \\
\hline \multirow{5}{*}{ FO } & Bentuk & $\mathrm{L}$ & $\mathrm{L}$ & $\mathrm{L}$ & $\mathrm{L}$ & $\mathrm{L}$ & $\mathrm{L}$ \\
\hline & $\mathrm{Bau}$ & TB & TB & TB & TB & TB & TB \\
\hline & Warna & B & B & B & B & B & B \\
\hline & Rasa & $\mathrm{Mm}$ & $\mathrm{Mm}$ & $\mathrm{Mm}$ & $\mathrm{Mm}$ & $\mathrm{Mm}$ & $\mathrm{Mm}$ \\
\hline & Pemisahan & TM & TM & TM & TM & TM & TM \\
\hline \multirow{5}{*}{$\mathrm{F} 1$} & Bentuk & $\mathrm{L}$ & $\mathrm{L}$ & PLT & PLT & PLT & PLT \\
\hline & Bau & KS & $\mathrm{KS}$ & KS & KS & KS & KS \\
\hline & Warna & $\mathrm{Kn}$ & $\mathrm{Kn}$ & $\mathrm{Kn}$ & $\mathrm{Kn}$ & $\mathrm{Kn}$ & $\mathrm{Kn}$ \\
\hline & Rasa & MmKK & MmKK & $\mathrm{MmKK}$ & MmKK & MmKK & MmKK \\
\hline & Pemisahan & TM & TM & TM & TM & TM & TM \\
\hline \multirow{5}{*}{ F2 } & Bentuk & $\mathrm{L}$ & $\mathrm{L}$ & $\mathrm{L}$ & $\mathrm{L}$ & $\mathrm{L}$ & $\mathrm{L}$ \\
\hline & Bau & KS & $\mathrm{KS}$ & $\mathrm{KS}$ & KS & KS & $\mathrm{KS}$ \\
\hline & Warna & KK & KK & KK & KK & KK & KK \\
\hline & Rasa & MmKK & MmKK & MmKK & MmKK & MmKK & MmKK \\
\hline & Pemisahan & TM & $\mathrm{TM}$ & $\mathrm{TM}$ & TM & TM & $\mathrm{TM}$ \\
\hline \multirow{5}{*}{ F3 } & Bentuk & $\mathrm{L}$ & $\mathrm{L}$ & $\mathrm{L}$ & $\mathrm{L}$ & $\mathrm{L}$ & $\mathrm{L}$ \\
\hline & Bau & $\mathrm{KS}$ & $\mathrm{KS}$ & $\mathrm{KS}$ & KS & KS & KS \\
\hline & Warna & KKP & KKP & KKP & KKP & KKP & KKP \\
\hline & Rasa & MmKK & MmKK & MmKK & MmKK & MmKK & MmKK \\
\hline & Pemisahan & TM & TM & TM & TM & TM & TM \\
\hline \multirow{5}{*}{$\mathrm{P}$} & Bentuk & $\mathrm{L}$ & $\mathrm{L}$ & $\mathrm{L}$ & $\mathrm{L}$ & $\mathrm{L}$ & $\mathrm{L}$ \\
\hline & $\mathrm{Bau}$ & KB & $\mathrm{KB}$ & KB & $\mathrm{KB}$ & KB & $\mathrm{KB}$ \\
\hline & Warna & CkMP & CkMP & CkMP & CkMP & CkMP & CkMP \\
\hline & Rasa & B & B & B & $\mathrm{B}$ & B & B \\
\hline & Pemisahan & TM & TM & TM & TM & TM & TM \\
\hline
\end{tabular}

Dimana FO = Formula basis sediaan kumur; F1: Formula sediaan kumur dengan konsentrasi ekstrak daun sukun 10\%; F2: Formula sediaan kumur dengan konsentrasi ekstrak daun sukun 15\%; F3: Formula sediaan kumur dengan konsentrasi ekstrak daun sukun 20\%; P: Formula Pembanding "BOK"; L: Larutan; TB: Tidak Berbau; KS: Khas Sukun; KK: Kuning Kecoklatan; KKP: Kuning Kecoklatan Pekat; Mm: Manis Menyegarkan; 
MmKS: Manis Menyegarkan Khas Sukun; KB: Khas "BOK”; B: Pembanding (“BOK”); CkMP: Coklat Kemerahan Peka: TM: Tidak Memisah.

Pemeriksaan viskositas sediaan obat kumur ekstrak daun sukun dilakukan dengan menggunakan viskometer ostwald. Viskositas suatu formula sangat mempengaruhi terhadap tingkat kekentalan produk tersebut saat digunakan berkumur didalam mulut. Hasil perhitungan viskositas menunjukan bahwa nilai viskositas formula obat kumur pada ekstrak daun sukun pada FO = 1,56 cp, F1 = 1,61 cp, F2 = 1,74 cp, F3 = 1,73 cp, P = 1,23 cp (Tabel 4).

Tabel 4 Pemeriksaan viskositas sediaan kumur ekstrak daun sukun dengan menggunakan viskometer Ostwald.

\begin{tabular}{|c|c|c|c|c|c|c|c|}
\hline \multirow[t]{2}{*}{ Formula } & \multicolumn{6}{|c|}{ Viskositas ( cP) Minggu ke - } & \multirow[t]{2}{*}{ Rata-rata $\pm \mathrm{SD}$} \\
\hline & 1 & 2 & 3 & 4 & 5 & 6 & \\
\hline F0 & 1,57 & 1,59 & 1,63 & 1,46 & 1,53 & 1,59 & $1,56 \pm 0,05$ \\
\hline $\mathrm{F} 1$ & 1,62 & 1,69 & 1,67 & 1,59 & 1,57 & 1,52 & $1,61 \pm 0,06$ \\
\hline F2 & 1,73 & 1,76 & 1,77 & 1,78 & 1,75 & 1,69 & $1,74 \pm 0,03$ \\
\hline F3 & 1,77 & 1,69 & 1,67 & 1,78 & 1,76 & 1,75 & $1,73 \pm 0,04$ \\
\hline $\mathrm{P}$ & 1,25 & 1,28 & 1,26 & 1,27 & 1,17 & 1,19 & $1,23 \pm 0,04$ \\
\hline
\end{tabular}

Dimana F0: Formula basis sediaan kumur; F1: Formula sediaan kumur dengan konsentrasi ekstrak daun sukun 10\%; F2: Formula sediaan kumur dengan konsentrasi ekstrak daun sukun 15\%; F3: Formula sediaan kumur dengan konsentrasi ekstrak daun sukun 20\%; P: Formula Pembanding "BOK".

\section{KESIMPULAN}

Berdasarkan hasil organoleptis pada uji stabilitas, uji $\mathrm{pH}$, uji viskositas pada penelitian ini dapat diambil kesimpulan bahwa ekstrak daun sukun dapat diformulasi dalam bentuk sediaan kumur.

\section{DAFTAR PUSTAKA}

Afrianti, R., Ramadheni, P., dan Irsanti, P. N. 2017. Uji Aktivitas Estrogenik Ekstrak Etanol Jintan Hitam (Nigella sativa L.) terhadap Perkembangan Uterus Tikus Putih Betina. Scientia, 7(1), 49-55.

Akarina, W. 2011. Pengaruh Konsentrasi Humektan terhadap Stabilitas Formula Obat Kumur. USU: Medan.

Aria, M., Fendri, S. T. J., dan Muqaddar, H. 2017. Uji Efek Stimulan Sistem Saraf Pusat Ekstrak Etanol Daun Pegagan (Centella asiatica (L.) Urban ) terhadap Mencit Putih Betina. Scientia, 7(1), 35-41

Barman, I., dan Prasad, U. C. 2015. Effects of Habitual Arecanut and Tobacco Chewing on Resting Salivary Flow Rate and pH. Int. J Oral Health Med Res. 2(1), 13-18.

Departemen Kesehatan RI. 1995. Farmakope Indonesia (Jilid IV). Dirjen POM. Jakarta.

Fendri, S. T. J., Tobat, S. R., dan Oktarihardi, F. 2018. Uji Efek Hepatoprotektif Ekstrak Jahe Merah (Zingiber officinale Var. Rubrum Theilade) Terhadap Tikus Putih Jantan. Scientia J. Far. Kes, 8(2), 153-161.

Harbone, J. B. 1987. Metode Fitokimia, Edisi ke dua. ITB. Bandung.

Hariana, H. A. 2008. Tumbuhan Obat dan Khasiatnya seri 2. Penebar Swadaya. Jakarta. 
Hidayatullah, Anam, S., dan Tandah, M. R. 201. Identifikasi Senyawa Antibakteri Ekstrak Metanol Daun Bamban (Donax canniformis (G. Forst.) K. Schum.) terhadap Staphylococcus aureus. Scientia, 7(2), 89-95

Lely, N., Nurhasana, F., dan Azizah, M. 2017. Aktivitas Antibakteri Minyak Atsiri Rimpang Lengkuas Merah (Alpinia purpuratak. Schum) terhadap Bakteri Penyebab Diare. Scientia, 7(1), 42-48.

Lely, N., Alantio, A., dan Noprizon. 2018. Uji Daya Antiinflamasi Ekstrak Etanol Daun Andong (Cordyline fruticosalinn) terhadap Radang Tikus Putih Jantan (Rattus novergicus). Scientia J. Far. Kes, 8(2), 8-18

Mardiana. 2013. Daun Ajaib Tumpas Penyakit. Penebar Swadaya. Jakarta.

Ningsih, W., Nofiandi, D., Deviarny, C., dan Roselin D. 2017. Formulasi dan Efek Antibakteri Masker Peel Off Ekstrak Etanol Daun Dewa (Gynura pseudochina (Lour.) Dc.) terhadap Staphylococcus epidermidis. Scientia, 7(1), 61-66.

Noviyanty, Y., dan Hepiyansori. 2018. Ekstrak Etanol Kulit Buah Mangga (Mangifera indica L) sebagai Formulasi Masker Gel. Scientia J. Far. Kes, 8(2), 162-168.

Rahim, F., Aria, M., dan Aji, N. P. 2011. Formulasi Krim Ekstrak Etanol Daun Ubi Jalar (Ipomoeae batatas L.) untuk Pengobatan Luka Bakar. Scientia, 1(1), 21-26.

Rahim, F., Yenti, R., Ningsih, W., Aprieskiy, R., dan Wahyuni, S. E. 2016. Cream Formulation Of Cyperus Rotundus L Rhizome Extract For Joint Pain Treatment. Journal of Chemical and Pharmaceutical Science, 9(3), 1339-1345.

Rahmi, M., Tobat, S. R., dan Ningsih, S. 2018. Uji Efek Stimulan Sistem Saraf Pusat Ekstrak Etanol Daun Afrika Selatan (Vernonia amygdalina Delile) pada Mencit Putih Betina. Scientia J. Far. Kes, 8(2), 137-143.

Sari, E. R., Hilma dan Cendrakasih, A. 2018. Penentuan Aktivitas Antioksidan Ekstrak Biji dan Daging Buah Karamunting (Rhodomyrtus tomentosa) W. Ait. Hassk Menggunakan Metoda DPPH. Scientia J. Far. Kes, 8(1),

Wijayanti, A., Rahardjo, A., dan Bahar, A. 2010. Perubahan Parameter Halitosis Setelah Penggunaan Siwak (Salvadora persica) pada Santri Pondok Pesantren Tapak Sunan Usia 11-13 Tahun. Ina J Dent Res, 17(2), 43-47.

Yulia, M., dan Hidayana, V. 2017. Uji Aktivitas Sitotoksik Ekstrak Etanol Daun Selasih (Ocimum basilicum L.) terhadap Larva Udang (Artemia salina Leach). Scientia, 7(2), 173-178. 